Rodolfo U. Fernandez III, MD

Department of Otorhinolaryngology Philippine General Hospital

University of the Philippines Manila
Correspondence: Dr. Rodolfo U. Fernandez III

Department of Otorhinolaryngology

Ward 10, Philippine General Hospital

Taft Avenue, Ermita, Manila 1000

Philippines

Phone (632) 5548467

Email: rufernandez.iii@gmail.com

The author declared that this represents original materia that is not being considered for publication or has not been published or accepted for publication elsewhere in full or in part, in print or electronic media; that the manuscript has been read and approved by the author, that the requirements for authorship have been met by the author, and that the author believe that the manuscript represents honest work.

The author signed disclosures that there are no financial or other (including personal) relationships, intellectual passion, political or religious beliefs, and institutional affiliations that might lead to a conflict of interest.

Presented at the Philippine Society of Otolaryngology Head and Neck Surgery Descriptive Research Contest, October 6, 2016. Natrapharm, The Patriot Bldg. Parañaque City.

\section{An Initial Overview of Management and Treatment Outcomes for Head and Neck Hemangiomas}

\begin{abstract}
Objectives: To provide an initial overview of the outcomes of different treatment modalities used for hemangiomas.

\section{Methods:}

$\begin{array}{ll}\text { Design: } & \text { Case Series } \\ \text { Setting: } & \text { Tertiary National University Hospital } \\ \text { Participants: } & \text { Records of } 21 \text { patients diagnosed with head and neck hemangiomas }\end{array}$ in the Philippine General Hospital Department of Otorhinolaryngology from 2009 to 2014 were reviewed.
\end{abstract}

Results: Majority of the patients were female (61.9\%) and in the pediatric age group (57.1\%). Of the 21 patients, 6 underwent medical management, 13 had surgical management, 1 had both medical and surgical management and 1 opted to observe the lesion. All patients treated with propranolol observed a decrease in the size of the lesion. Seven out of the 13 patients had radiofrequency ablation; all had gross residual lesion. Six of the 13 underwent excision with complete excision being achieved in 5 of 6 cases.

Conclusion:Treatment response of patients in this series with hemangiomas of the head and neck to propranolol at a dose of 1 to $2 \mathrm{mg} / \mathrm{kg} /$ day may reflect international data. Outcomes analysis for radiofrequency ablation and surgical excision requires a longer duration of follow-up.

Keywords: propranolol hydrochloride, prednisone, pulsed radiofrequency treatment, capillary hemangioma, vascular tissue neoplasms

Hemangiomas are the most common benign vascular tumors in infancy (but may also involve adults) and most commonly affect the head and neck region.' Unlike other vascular tumors, hemangiomas have a characteristic natural course-- they rapidly proliferate during infancy and gradually involute over the next few years of life. However, a small proportion of hemangiomas require intervention. Indications for intervention include function-threatening hemangiomas (e.g. ocular, ear, nasal tip and genitalia), life-threatening hemangiomas (e.g. airway lesion), disfiguring large hemifacial hemangiomas, ulcerated hemangiomas and those with associated systemic involvement. ${ }^{1}$ 
ORIGINAL ARTICLES

Systemic corticosteroids (e.g. prednisone at a dose of $2-4 \mathrm{mg} / \mathrm{kg} /$ day) have been used as the first line treatment for hemangiomas for many years but long-term side effects of systemic steroids have been a recurring problem. ${ }^{1}$ Recently, non-selective beta-blockers such as propranolol and timolol have emerged as safer and more promising treatment modalities.' Other treatment options include the use of intralesional triamcinolone, topical steroids such as clobetasol propionate, topical imiquimod and pulse dye laser ${ }^{1-3}$ With the failure of medical management, surgical modalities come into play.

In the Philippine General Hospital, hemangiomas are independently managed by different units which include Pediatrics, Plastic Surgery, Dermatology and Otorhinolaryngology. The objective of this study is to provide an initial overview of the outcomes of different treatment modalities for patients with hemangiomas of the head and neck of the Department of Otorhinolaryngology from 2009 to 2014.

\section{METHODS}

With Institutional Review Board approval, this case series purposively identified patients diagnosed with head and neck hemangiomas between January 2009 to December 2014 from outpatient, in patient, and emergency room censuses of the Philippine General Hospital (PGH) Department of Otorhinolaryngology, and retrieved their medical records for review.

Excluded were records of patients with a post-treatment followup of less than 6 months or who were lost to follow-up before or after treatment, those who did not comply with the medical treatment regimen, and those whose records were incomplete or missing.

Demographic data, location and size of lesion were extracted from the records. For patients treated medically, the following were determined: drug used, method of delivery, dose, duration of treatment, and treatment outcome (complete resolution, no change, decrease or increase in size, change in color). For patients treated surgically, the following were determined: type of surgery and outcome (complete resection, partial resection with gross residual). Information was anonymized, recorded and tabulated using Microsoft ${ }^{\oplus}$ Excel for Mac 2015 Version 15.13.3 (150815) (Microsoft Corp., Redmond, WA, USA) and descriptive statistics were computed.

\section{RESULTS}

Out of 41 identified patients from the databases, only 21 fulfilled inclusion and exclusion criteria, 8 males (38.1\%) and 13 females (61.9\%). The age range was 0.75 to 66 years and a mean age of 18.1 years (SD $=17.2$ ). Twelve $(57.1 \%$ ) belonged to the pediatric age group (0 to 17 years) while $9(42.8 \%)$ were adults. Six patients underwent medical management, 13 had surgical management, 1 had both medical and
Table 1. Medical Management Group

\begin{tabular}{|c|c|c|c|c|c|c|c|}
\hline $\begin{array}{c}\text { Patient } \\
\text { Code }\end{array}$ & $\begin{array}{l}\text { Age/ } \\
\text { Sex }\end{array}$ & $\begin{array}{c}\text { Location } \\
\text { of } \\
\text { lesion }\end{array}$ & $\begin{array}{c}\text { Size of } \\
\text { lesion } \\
(\mathrm{cm})\end{array}$ & Drug & $\begin{array}{c}\text { Dose } \\
\text { (mg/ } \\
\text { kg/ } \\
\text { day) }\end{array}$ & $\begin{array}{c}\text { Dura- } \\
\text { tion } \\
\text { of } \\
\text { treat } \\
\text { ment } \\
\text { (months) }\end{array}$ & $\begin{array}{l}\text { Out- } \\
\text { come }\end{array}$ \\
\hline M1 & $8 / M$ & lip & $\begin{array}{c}1 \times 1 x \\
0.5\end{array}$ & $\begin{array}{c}\text { oral } \\
\text { propranolol }\end{array}$ & 1.25 & 12 & $\begin{array}{l}\text { decrease } \\
\text { in size }\end{array}$ \\
\hline M2 & $\begin{array}{c}9 \\
\text { mo }\end{array}$ & buccal & $8 \times 6 \times 2$ & $\begin{array}{c}\text { oral } \\
\text { prednisone }\end{array}$ & 1 & 3 & no change \\
\hline & $s / F$ & & & $\begin{array}{c}\text { oral } \\
\text { propranolol }\end{array}$ & 2 & 6 & $\begin{array}{l}\text { decrease } \\
\text { in size }\end{array}$ \\
\hline M3 & $8 / F$ & lip & $5 \times 2 \times 1$ & $\begin{array}{c}\text { oral } \\
\text { prednisone }\end{array}$ & 1 & 1.5 & no change \\
\hline \multirow[t]{2}{*}{ M4 } & \multirow[t]{2}{*}{$4 / F$} & \multirow[t]{2}{*}{ nasal } & \multirow{2}{*}{$\begin{array}{c}1 \times 1 x \\
0.5\end{array}$} & $\begin{array}{c}\text { intralesional } \\
\text { methyl } \\
\text { prednisolone }\end{array}$ & $\begin{array}{l}1.5 q 1 \\
\text { month }\end{array}$ & 3 & $\begin{array}{l}\text { decrease } \\
\text { in size }\end{array}$ \\
\hline & & & & $\begin{array}{c}\text { oral } \\
\text { propranolol }\end{array}$ & 2 & 20 & $\begin{array}{l}\text { decrease } \\
\text { in size }\end{array}$ \\
\hline M5 & $6 / F$ & temporal & $\begin{array}{c}4.5 \times 5 \\
\times 1\end{array}$ & $\begin{array}{c}\text { oral } \\
\text { propranolol }\end{array}$ & 2 & 2 & $\begin{array}{l}\text { decrease } \\
\text { in size }\end{array}$ \\
\hline M6 & $4 / F$ & tongue & $\begin{array}{c}10 \times 8 \\
\times 8\end{array}$ & $\begin{array}{c}\text { oral } \\
\text { propranolol }\end{array}$ & 1 & 6 & $\begin{array}{l}\text { decrease } \\
\text { in size }\end{array}$ \\
\hline
\end{tabular}

surgical management, and 1 patient opted to observe the lesion.

All 5 patients who underwent medical management with propranolol doses ranging from 1 to $2 \mathrm{mg} / \mathrm{kg} /$ day for at least 2 months were reported to have a decrease in size of their hemangiomas. Of the 5, one (M2) was initially treated with oral prednisone (without response) and another (M4) received intralesional methylprednisolone (with decrease in size) prior to propranolol therapy. Another patient (M3) who underwent treatment with oral prednisone alone exhibited no change in hemangioma size. (Table 1)

Of the 13 surgical patients, 7 underwent radiofrequency ablation: 4 for lip lesions and one each for the chin, cheek and nasolabial area. Two of these patients $(\mathrm{S} 5, \mathrm{~S} 7)$ had prior surgeries. All 7 had gross residual lesions after the procedure. Of the six patients that underwent excision, complete excision was claimed in 5 of 6 cases while 1 case had gross intracranial residual tumor. (Table 2)

The one patient who underwent both medical and surgical management was a 30-year-old man with a hemangioma in the right buccal area that was surgically excised. Due to recurrence, he underwent medical management with Nebivolol at a dose of $0.5 \mathrm{mg} / \mathrm{kg} / \mathrm{day}$ for 24 months. A decrease in size of the lesion was reported after 2 years. The one patient who opted to observe the lesion (a 3-year old female with a right pre-auricular hemangioma) was reported to have spontaneous resolution of her lesion after 4 years. 
Table 2. Surgical Management Group

\begin{tabular}{|c|c|c|c|c|c|c|}
\hline $\begin{array}{c}\text { Patient } \\
\text { Code }\end{array}$ & $\begin{array}{l}\text { Age/ } \\
\text { Sex }\end{array}$ & $\begin{array}{c}\text { Location } \\
\text { of } \\
\text { lesion }\end{array}$ & $\begin{array}{l}\text { Size of } \\
\text { lesion } \\
(\mathrm{cm})\end{array}$ & $\begin{array}{c}\text { Surgery } \\
\text { done }\end{array}$ & $\begin{array}{c}\text { Prior } \\
\text { Surgery }\end{array}$ & $\begin{array}{l}\text { Out- } \\
\text { come }\end{array}$ \\
\hline S1 & $18 / F$ & chin & $5 \times 5 \times 2$ & RF ablation & none & $\begin{array}{l}\text { gross } \\
\text { residual }\end{array}$ \\
\hline S2 & $18 / F$ & cheek & $\begin{array}{c}4 \times 4 x \\
0.5\end{array}$ & RF ablation & none & $\begin{array}{l}\text { gross } \\
\text { residual }\end{array}$ \\
\hline S3 & $66 / \mathrm{M}$ & nasolabial & $\begin{array}{c}2 \times 2.5 x \\
0.5\end{array}$ & RF ablation & none & $\begin{array}{c}\text { gross } \\
\text { residual }\end{array}$ \\
\hline S4 & $11 / F$ & lip & $\begin{array}{c}3 \times 3 x \\
2.5\end{array}$ & RF ablation & none & $\begin{array}{c}\text { gross } \\
\text { residual }\end{array}$ \\
\hline S5 & $3 / M$ & lip & $\begin{array}{c}1 \times 1 x \\
0.5\end{array}$ & RF ablation & $\begin{array}{c}\mathrm{RF} \\
\text { ablation } \\
\times 2\end{array}$ & $\begin{array}{c}\text { gross } \\
\text { residual }\end{array}$ \\
\hline S6 & $4 / F$ & lip & $2 \times 2 \times 1$ & RF ablation & none & $\begin{array}{c}\text { gross } \\
\text { residual }\end{array}$ \\
\hline S7 & $20 / M$ & lip & $5 \times 4 \times 1$ & RF ablation & excision & $\begin{array}{c}\text { gross } \\
\text { residual }\end{array}$ \\
\hline S8 & $15 / M$ & temporal & $10 \times 8 \times 7$ & excision & none & $\begin{array}{l}\text { complete } \\
\text { excision }\end{array}$ \\
\hline S9 & $20 / M$ & intranasal & $5 \times 5 \times 3$ & $\begin{array}{c}\text { excision } \\
\text { via lateral } \\
\text { rhinotomy }\end{array}$ & none & $\begin{array}{l}\text { complete } \\
\text { excision }\end{array}$ \\
\hline $\mathrm{S} 10$ & $21 / \mathrm{M}$ & $\begin{array}{l}\text { gingivo- } \\
\text { buccal }\end{array}$ & $\begin{array}{c}2.5 \times 2.5 \\
\times 2\end{array}$ & excision & none & $\begin{array}{l}\text { complete } \\
\text { excision }\end{array}$ \\
\hline S11 & $37 / F$ & intranasal & $1 \times 1 \times 1$ & $\begin{array}{c}\text { endoscopic } \\
\text { excision }\end{array}$ & none & $\begin{array}{l}\text { complete } \\
\text { excision }\end{array}$ \\
\hline S12 & $26 / M$ & lip and buccal & $6 \times 5 \times 4$ & $\begin{array}{c}\text { excision with } \\
\text { deltopectoral } \\
\text { flap } \\
\text { reconstruction }\end{array}$ & none & $\begin{array}{l}\text { complete } \\
\text { excision }\end{array}$ \\
\hline S13 & $58 / F$ & $\begin{array}{c}\text { temporal with } \\
\text { intracranial } \\
\text { extension }\end{array}$ & $10 \times 8 \times 5$ & $\begin{array}{c}\text { wide } \\
\text { excision via } \\
\text { transtemporal } \\
\text { approach with } \\
\text { trapezius flap } \\
\text { reconstruction }\end{array}$ & none & $\begin{array}{c}\text { gross } \\
\text { residual } \\
\text { (intracranial) }\end{array}$ \\
\hline
\end{tabular}

\section{DISCUSSION}

All patients who underwent treatment with oral propranolol in this series were reported to have had a decrease in size in their lesions while those who underwent treatment with oral prednisone had no change in their lesions. The propranolol treatment group had a treatment dose ranging from $1-2 \mathrm{mg} / \mathrm{kg} /$ day and a mean duration of 9.3 months (range of 2 to 20 months).

The lesion observed in one patient that was reported to spontaneously resolve after 4 years may be explained by the natural history of infantile hemangiomas-- a rapid proliferative phase followed by a slower phase of involution. ${ }^{1,4}$ It is important to note that the majority of infantile hemangiomas undergo spontaneous resolution and that only 10 to $20 \%$ of patients require treatment. 'If such is the case, why treat infantile hemangiomas with propranolol to begin with? Why not wait for spontaneous resolution (which should happen in most cases) and treat only those that do not resolve? The decision to treat an infantile hemangioma or wait for spontaneous resolution depends on the indication for intervention which includes function-threatening hemangiomas (e.g. ocular, ear, nasal tip and genitalia), life-threatening hemangiomas (e.g. airway lesion), disfiguring large hemifacial hemangiomas and ulcerated hemangiomas. 'It must also be noted that the use of oral propranolol therapy for infantile hemangiomas has contraindications (e.g. sinus bradycardia, bronchial asthma, heart failure) and is associated with several adverse effects (e.g. bradycardia, hypotension, hyperkalemia, hypoglycemia, bronchospasm) therefore, the decision to treat is highly individualized. ${ }^{4}$ The possible risks and adverse effects should be weighed against the potential benefits of intervention before starting treatment. ${ }^{4}$

The target dose of propranolol of $1-3 \mathrm{mg} / \mathrm{kg} /$ day has been recommended with a mean duration of treatment varying from 6 to 10 months. ${ }^{4} \mathrm{~A}$ meta-analysis by Marqueling et al. showed that the overall response rate is $98 \%$ with a range of 82 to $100 \% .{ }^{5}$ The 2 patients who took Prednisone with a dose of $1 \mathrm{mg} / \mathrm{kg} /$ day with a mean duration of 2.25 months (range of 1.5 to 3 months) had no response and this may be attributed to an insufficient dose (recommended dose ranges from $2-5 \mathrm{mg} / \mathrm{kg} /$ day). For Prednisone, the recommended dose is $2-4 \mathrm{mg} / \mathrm{kg} /$ day. ${ }^{6}$ In a study by Benett et al., a dose of $2-4 \mathrm{mg} / \mathrm{kg} /$ day resulted in $75 \%$ response, $>3 \mathrm{mg} / \mathrm{kg} /$ day showed $94 \%$ response but with greater side effects while a lesser dose of $<2 \mathrm{mg} / \mathrm{kg} /$ day resulted in poor response and rebound phenomenon in $70 \%$ of cases. ${ }^{6}$ Sawa et al. found excellent treatment response to both propranolol and prednisone for infantile hemangiomas, at a median dose of $5 \mathrm{mg} / \mathrm{kg} /$ day for prednisone $(\mathrm{n}=11)$ and $2 \mathrm{mg} / \mathrm{kg} /$ day for propranolol $(\mathrm{n}=7)$. $^{7}$ The difference between the two drugs was significantly longer treatment duration for propranolol with a mean duration of 372 days.? Side effects of corticosteroid treatment noted were increase in body-mass index (BMI) and systolic blood pressure.

Propranolol is well documented as an effective treatment modality for infantile hemangiomas. ${ }^{1,4,5,7}$ Its mechanism of action in hemangiomas is related to its beta- 2 inhibitory effect which decreases the release of vasodilators such as nitric oxide. Vasoconstriction of the feeding capillaries results for the early visible changes in the color of the lesion. ${ }^{1}$ Furthermore, propranolol down-regulates vascular endothelial growth factors and basic fibroblast growth factors, inhibiting the proangiogenic cascade and angiogenesis. This results in apoptosis and regression of hemangiomas.' 
Complete removal of lesions through radiofrequency ablation is difficult to achieve, hence it is done multiple times per patient. However, it has been proven a safe and effective surgical modality for the treatment of hemangiomas because incisions are not required with pain and bleeding kept at a minimum. ${ }^{8}$ In this series, 7 patients underwent radiofrequency ablation, all with gross residual lesions posttreatment. Among these patients, 5 lesions involved the lip. It may be surmised that the location of the hemangioma may influence the type of surgical intervention. Six patients underwent surgical excision with 5 of 6 cases claimed to have achieved complete excision.

A major limitation of this study is that as a review of case records, outcome observations of propranolol and prednisone therapy were made by multiple observers and recorded observations could not be verified. The variables of measure were neither standardized nor quantified. Future prospective studies should include photographic documentation and standardized measurements of tumor volume. The failure to serially analyze outcomes of radiofrequency ablation patients who had prior surgeries, as well as the short duration of follow-up for patients who underwent radiofrequency ablation and surgical excision are further limitations of this study. It is recommended that a longer follow-up for this subset of hemangioma patients be performed in order to adequately analyze the outcomes of each radiofrequency ablation procedure and to document any recurrences after surgical excision.

In conclusion, the treatment response of patients in this series with hemangiomas of the head and neck to propranolol at a dose of 1 to $2 \mathrm{mg} / \mathrm{kg} /$ day may reflect international data. Outcomes analysis for radiofrequency ablation and surgical excision requires a longer duration of follow-up.

\section{ACKNOWLEDGEMENTS}

I would like to acknowledge my adviser, Dr. CesarV.Villafuerte, Jr. for his guidance in the execution and writing of this research paper. Also, I would like to acknowledge Dr. Precious Eunice R. Grullo for her invaluable assistance in revising this paper.

\section{REFERENCES}

1. Sethuraman G, Yenamandra VK, Gupta V. Management of infantile hemangiomas: current trends. J Cutan Aesthet Surg. 2014 Apr;7(2):75-85. DOI: 10.4103/0974-2077.138324; PubMed PMID: 25136206 PMCID: PMC4134656.

2. Couto J, Greene A. Management of problematic infantile hemangioma using intralesional triamcinolone: efficacy and safety in 100 infants. J Plast Reconstr Aesthet Surg. 2014 Nov 67(11):1469-1474. DOI: 10.1016/j.bjps.2014.07.009; PMID: 25104131.

3. Garzon MC, Lucky AW, Hawrot A, Frieden IJ. Ultrapotent topical corticosteroid treatment of hemangiomas of infancy. J Am Acad Dermatol. 2005 Feb; 52(2):281-286. DOI: 10.1016/j. jaad.2004.09.004; PMID: 15692474

4. Drolet BA, Frommelt PC, Chamlin SL, Haggstrom A, Bauman NM, Chiu YE, et al. Initiation and use of propranolol for infantile hemangioma: report of a consensus conference. Pediatrics. 2013 Jan;131(1):128-140. DOI: 10.1542/peds.2012-1691; PMID: 23266923; PMCID: PMC3529954.

5. Marqueling AL, Oza V, Frieden IJ, Puttgen KB. Propranolol and infantile hemangiomas four years later: a systematic review. Pediatr Dermatol. 2013 Mar-Apr; 30(2):182-191. DOI: 10.1111/ pde.12089; PMID: 23405852.

6. Bennett ML, Fleischer AB Jr, Chamlin SL, Frieden IJ. Oral corticosteroid use is effective for cutaneous hemangiomas: an evidence-based evaluation. Arch Dermatol. 2001 Sep; 137(9): 1208-13. PMID: 11559219.

7. Sawa K, Yazdani A, Rieder MJ, Filler G. Propranolol therapy for infantile hemangioma is less toxic but longer in duration than corticosteroid therapy. Plast Surg. 2014 Winter; 22(4): 233-236. PMID: 25535459; PMCID: PMC4271750.

8. Bozan N, Gur MH, Kiroglu AF, Cankaya H, Garca MF. Tongue Hemangioma: A Case Report. Van Tip Dergisi. 2014; 21 (2): 120-122. 